\title{
A SEQUENTIAL EQUILIBRIUM FOR THE ARMY'S TARGETED SELECTIVE REENLISTMENT BONUS PROGRAM
}

\author{
SCOTT E. CARRELL AND JAMES E. WEST
}

We compute a sequential equilibrium for the U.S. Army's Targeted Selective Reenlistment Bonus Program in which the Army offers a bonus, soldiers with a low cost of serving in an undesirable location accept the bonus and are sent to an undesirable location, and soldiers with a high cost of serving in an undesirable location reenlist but decline the bonus. We find that this program benefits both the Army and soldiers, increases retention, increases the number of soldiers who serve in an undesirable location, and better matches soldiers to assignments. We discuss implications of our model on human resource management practices for the Army in its administration of the bonus program and its application to other large organizations that set wages through a rules-based mechanism. (C) 2007 Wiley Periodicals, Inc.

\section{INTRODUCTION}

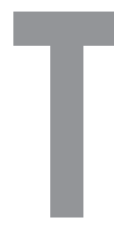

hroughout the last century, the U.S. military has sent large numbers of its members to relatively undesirable locations throughout the world. With the advent of an all-volunteer military force, the attractiveness of choosing military service could arguably be diminished by an increased probability of being sent to such locations, adversely affecting both recruitment of new members and retention of existing members. Since 1999, the U.S. Army has been offering a bonus called the Targeted Selective Reenlistment Bonus (TSRB) to soldiers who reenlist and volunteer to be sent to undermanned, and presumably less desirable, locations.

From a personnel management perspective, can location-specific bonuses, such as the Army Targeted Selective Reenlistment Bonus program, effectively boost reenlistment rates at a lower cost to the Army than across-the-board pay increases? To address this question, we first provide some back-

The views expressed in this article are those of the author and do not necessarily reflect the official policy or position of the United States Air Force, Department of Defense, or the U.S. government.

Correspondence to: James E. West, Department of Economics and Geosciences, 2354 Fairchild Drive, \#6K100, USAF Academy, CO 80840, Phone: 719-333-8735, Fax: 719-333-7137, E-mail: Jim.West@usafa.edu 
ground on the Army and examine the relevant human resource management and economics literature. Next, we examine the problem from a high-level, narrative approach. Finally, we employ game theoretic modeling methods to analyze the TSRB program as a sequential game. Game theoretic methods will add to the article by explicitly showing what conditions are necessary for the TSRB to benefit both the Army and soldiers. Using the reenlistment rates, results of our model, we discuss human resource management immilitary leaders either must raise plications both for the Army and for other large organizations.

wages across the

board, preserving

uniformity of wages,

or somehow boost

wages in locations

where wages are

relatively low.

\section{Military Background and Literature Review}

To somebody who enlists in the Army, a whole new world awaits, complete with its own vocabulary of terms and acronyms. Once a soldier has completed basic training and any occupation-specific training, s/he incurs an obligation to remain in the Army for a period of 2-6 years-referred to as a service commitment. Once the service commitment has expired, the soldier is not under obligation to remain in the Army unless a stop-loss is declared. A stoploss is a situation in which critical shortages exist and current members of the military are not permitted to leave. Presuming a stop-loss is not in effect and a soldier wants to remain within the Army, s/he must first be approved for reenlistment by their company commander. The soldier can reenlist for between 2 and 6 years. Once reenlisted, a soldier may request assignment to a specific location or career specialization, but the Army is under no obligation to honor such requests. The Army is very explicit that soldiers will be assigned according to the needs of the Army. Given this uncertainty, a soldier contemplating reenlistment would carefully consider the likelihood of being involuntarily sent to an undesirable location after reenlistment.

All branches of the military have historically offered a single, nationwide base salary that varies only by military rank and years of service, referred to as basic pay. Members of the military also receive Basic Allowance for Subsistence (BAS), a flat sum that does not vary by rank or years of service. ${ }^{1}$ Members also receive a housing allowance, Basic Allowance for Housing (BAH), the intent of which is to enable those of the same rank to afford comparable housing in whatever location they are stationed. This variability in military wages by location is not as great as that observed in civilian wages for comparable experience and skill levels (Carrell \& West, 2005). In the economic boom times of the late 1990s, rising civilian wages relative to military wages resulted in unacceptably low retention rates. To combat this discrepancy, in 1999, the U.S. Army began offering reenlistment bonuses to soldiers that varied by rank, occupation, and location, called the Targeted Selective Reenlistment Bonus program. Soldiers who agree to reenlist and serve in an undesirable location received a cash bonus.

In a competitive (civilian) labor market, local wages should adjust to reflect differing local costs, desirability, and amenities (Blomquist, Berger, \& Hoehn, 1988; Graves, 1999; Haurin, 1980; Rosen, 1979). The traditional structure of military wages, by not fully adjusting for local cost of living and amenities, leads to decreased retention in areas where military wages are low relative to local civilian wages (Carrell \& West, 2005). To raise reenlistment rates, military leaders either must raise wages across the board, preserving uniformity of wages, or somehow boost wages in locations where wages are relatively low. The TSRB is an implementation of the latter approach.

Local labor market conditions have been shown to affect local military recruitment. As described by Brown (1985), "[t]he combination of sizeable unemployment elasticities and major swings in the regional concentration of unemployment had significant effects on the regional distribution of Army enlistees. During the sample period (1976-82), the Midwest replaced the South as the dominant per capita supplier of recruits to the volunteer Army" (p. 233).

As further evidence that military retention rates respond to changes in pay, Fuller- 
ton (2003) considers the effect of bonuses paid to Air Force pilots who agree to remain in the Air Force beyond the minimum time required for going through pilot training. The bonuses were found to be effective in increasing retention, and for every dollar paid in bonuses under the Aviation Continuance Pay program, approximately $\$ 10$ in training and replacement costs were avoided due to increased pilot retention.

Turning to the human resources literature, a lively debate exists about the effect of pay on employee behavior, including turnover. "In their comprehensive review of employee turnover, Hom and Griffeth (1995) maintain that although both employers and employees perceive pay as playing a central role in turnover, many academics in the organizational sciences have traditionally downplayed its importance" (Guthrie, 2000, p. 419). When asked directly about its importance as a job attribute, major surveys rank the importance of pay between second and eighth (Herzberg, Mausner, Peterson, \& Capwell, 1957; Jurgensen, 1978; Lawler, 1971; Towers Perrin, 2003). However, when asked to rank groups of hypothetical jobs in which characteristics have been engineered in such a way as to enable researchers to sort out the importance of individual characteristics, pay appears to be substantially more important (Barber, 1998; Rynes, Schwab, \& Heneman, 1983; Schwab, 1982). According to Rynes, Gerhart, and Minette (2004) “... pay level is likely to be quite important both in attracting employees (Rynes et al., 1983) and in retaining them (Delery, Gupta, Shaw, Jenkins, \& Ganster, 2000; Guthrie, 2000)" (p. 388-389).

Numerous studies in the economics literature find military retention rates to be very responsive to increases in military pay relative to civilian pay (Asch \& Warner, 2001; Daula \& Moffitt, 1995; Hosek \& Peterson, 1985; Saving, Stone, Looper, \& Taylor, 1985; Warner \& Goldberg, 1984). But computing the responsiveness of military retention to changes in relative wages may overlook inefficiencies that exist within the military (or other large organizations) due to inflexible wages set internally, or within the organiza- tion, by a rules-based system. Economists refer to such a system as an internal labor market. As Doeringer and Piore (1971) describe the internal labor market:

... an administrative unit, such as a manufacturing plant, within which the pricing and allocation of labor is governed by a set of administrative rules and procedures. The internal labor market, governed by administrative rules, is to be distinguished from the external labor market of conventional economic theory where pricing, allocating, and training decisions are controlled directly by economic variables. (pp. 1-2)

Following Coasean logic, rules-based compensation systems have the benefits of reduced administrative costs, perception of equity, and reduced favoritism (Gibbs \& Hendricks, 2004; Milgrom, 1988; Milgrom \& Roberts, 1988; Prendergast, 1993; Prendergast \& Topel, 1996). Costs of rules-based compensation systems have not been studied as extensively in the economics literature, nor is there consensus on their effects. One recent study found that wage constraints imposed by a rules-based system "apparently did not impose important costs on the firm in the form of increased turnover" (Gibbs \& Hendricks, 2004, p. 1). Another study found that within a rules-based system, those who are promoted the fastest are also more likely to leave (Baker, Gibbs, \& Holmstrom, 1994).

Likewise, the human resources literature has found benefits to group-based compensation plans. Guthrie (2000) examines the effects of group-based pay plans, in which wages are tied to group performance, on employee retention. Although a locationspecific bonus would not necessarily be tied to group performance in that location, it is 
nonetheless still a group-based compensation plan. He finds that group-based pay plans do enhance retention, and that the changes in retention occur primarily in lower-ability or -performing employees (Guthrie, 2000).

\section{Army versus Navy Local Wages}

The Army and Navy have taken different approaches to local adjustment of wages. In 2003, the Navy launched a pilot program called

In contrast to the

Navy's AIP, which

relies on sailors to

reveal their desired

bonuses through a

market mechanism,

the Army's TSRB is

more in line with a

traditional military

manning system, in

which pay is

determined by the

Army, and soldiers

choose to accept or

reject the offer

presented. Assignment Incentive Pay (AIP), in which sailors can submit bids online for the amount of additional compensation they would require to accept an undermanned and presumably undesirable assignment. For each assignment placed within the AIP system, the Navy posts a maximum allowed bid, although individual sailors cannot observe what other sailors have bid. Navy detailers then select the winning sailor on the basis of total cost to the Navy, defined to be the sum of AIP payments, training costs, Permanent Change of Station ${ }^{2}$ costs, and costs of any "gap" in the billet. ${ }^{3}$ From its inception to May 2004, more than 2,400 AIP bids were received by the Navy, and 644 sailors received an average of $\$ 245$ in extra pay per month (MCPON Minute, 2004). The Navy plans to eventually expand AIP to cover all enlisted billets (Hogan \& Mackin, 2003). This approach enables sailors to self-identify who is willing to accept undesirable assignments at lowest wages. The result would be economically efficient sorting. This system stops short of fully flexible wages, as sailors are not permitted to enter negative bids for positions that are overstaffed (Jaffe, 2003).

Allowing sailors to bid in a limited marketplace for the bonus they would require to accept an undesirable location has many virtues. Sailors willing to be stationed at undesirable locations at the lowest cost would have a monetary incentive to reveal themselves and their minimum acceptable bonus to the Navy. Undesirable locations would now be manned by willing (and presumably happier) sailors at minimal cost to the Navy. But some in the military community worry that paying bonuses for undesirable duties and the possibility of those performing identical duties getting unequal pay might undercut military morale and discipline (Jaffe, 2003).

An alternative approach is the Army's Targeted Selective Reenlistment Bonus program. In contrast to the Navy's AIP, which relies on sailors to reveal their desired bonuses through a market mechanism, the Army's TSRB is more in line with a traditional military manning system, in which pay is determined by the Army, and soldiers choose to accept or reject the offer presented. Since 1999, the U.S. Army has offered additional reenlistment bonuses to personnel who, in conjunction with a reenlistment, volunteer to serve in a location with low manning levels (within the respective rank and occupation). Low manning levels in a location are primarily due to lower-than-average reenlistment rates at that location. These locations, therefore, are considered "undesirable," and bonuses are offered to entice personnel to voluntarily serve at these locations.

Bonus amounts vary by occupation, rank, and location. For example, in FY02, a sergeant (E5) in the Infantry with four years of service would have received an additional reenlistment bonus of over $\$ 3,600$ for a fouryear reenlistment to Fort Drum, New York. The Army varies bonus amounts on a quarterly basis depending on current manning levels and projected requirements. The total cost of the SRB/TSRB program was over $\$ 112$ million in FY01, $\$ 89$ million in FY02, and over $\$ 110$ million in FY03. ${ }^{4}$

One might wonder how the military benefits from local variation of wages. Military personnel are required to serve in a location, regardless of their taste preferences. The military could simply "non-volunteer" person- 
nel to serve at undesirable locations. ${ }^{5}$ However, Carrell and West (2005) show how a voluntary system of assignments, compared to a nonvoluntary system, location by location minimizes the opportunity cost summed over all military personnel serving at each location. Minimizing opportunity costs of soldiers/sailors/airmen leads to better sorting of personnel and increased production efficiency, and likely leads to increased retention levels, ${ }^{6}$ benefiting the military as well as those who serve in it.

\section{A Tale of Two Soldiers and Two Locations}

To first examine the feasibility and operation of the TSRB at a higher level of detail, consider an army of two. These two soldiers, Angie and Ben, are eligible to leave the Army, as their enlistment has expired. The Army very much needs both Angie and Ben to reenlist, and needs one to serve at Ft. Carson (a very desirable base in Colorado Springs, Colorado) and the other to serve abroad in a combat zone in the desert (considered to be less desirable). The Army does not care which soldier is assigned to which location but needs both locations to be filled, and Angie and Ben are the only two soldiers who can do either job.

The only information the Army has about Angie and Ben are their military ranks, job skills, and past performance reviews. Assume that to the Army, they are essentially indistinguishable. But Angie and Ben have somewhat different preferences over the possible locations they could be stationed at. Suppose that Angie thoroughly enjoys every aspect of Army life. As such, she would be willing to serve at either location for a lower monthly salary than Ben, without additional incentives. Although Ben does like the Army, he would require a substantially higher wage to voluntarily agree to be deployed to the desert. Suppose the minimum monthly wage at which each soldier would voluntarily serve at either location (reservation wage) is as given in Table I.

If the Army offered only one wage that did not vary by location, consider what would happen if it offered Angie and Ben each $\$ 3,000$ per month. If Angie were to reenlist and were sent to Ft. Carson, she would be paid $\$ 3,000$, when she would have willingly accepted for only $\$ 1,500$. Her gain, or economic surplus, is $\$ 3,000-$ $\$ 1,500=\$ 1,500$. If, instead, she were deployed to the desert, her surplus would be $\$ 3,000-\$ 2,000=\$ 1,000$. At the time of reenlistment, Angie does not know where she will be stationed. Since Angie could expect to be deployed to either location with equal probability, her expected surplus would be $0.5 * \$ 1,500+0.5 * \$ 1000=$ $\$ 1,250$. Angie would happily reenlist. Following similar logic, Ben's surplus at Ft. Carson would be $\$ 1,000$ and $\$ 0$ in the desert. His expected surplus across both locations would be $\$ 500$. Ben would gladly reenlist as well. The lowest uniform monthly wage at which both would reenlist would be $\$ 2,500$. This wage gives Ben an expected surplus of $\$ 0$ and Angie an expected surplus of $\$ 750$.

Consider what would happen if the Army set a wage below $\$ 2,500$. Ben would be willing to accept a wage as low as $\$ 2,000$ if he knew he would be assigned to Ft. Carson with certainty. Since he faces a 50\% chance of being deployed to the desert, Ben requires a higher wage to compensate for this risk. Consequently, Ben will not reenlist. Recall that the Army does not know the

\section{T A B L E I Reservation Wage by Soldier and Location}

$\begin{array}{lll} & \text { Ft. Carson } & \text { Desert } \\ \text { Angie } & \$ 1,500 & \$ 2,000 \\ \text { Ben } & \$ 2,000 & \$ 3,000\end{array}$


reservation wages of each soldier by location contained in Table I but must set the monthly wage without this knowledge. Suppose the Army set monthly wages to $\$ 2,500$ and asked Angie and Ben where they would prefer to be stationed. Angie would gain a surplus of $\$ 2,500-\$ 1,500=\$ 1,000$ from being stationed at Ft. Carson, and $\$ 2,500-\$ 2,000=\$ 500$ from serving in the desert. She will request Ft. Carson. Ben would gain $\$ 2,500-\$ 2,000=\$ 500$ by serving at Ft. Carson, and lose $\$ 2,500-\$ 3,000$ $=-\$ 500$ being deployed to the desert. Ben, too, will request Ft. Carson. The Army needs an incentive system by which Angie, who has a lower "cost" of being deployed to the desert, will self-identify.

Consider Angie and Ben's aclower base salaries tions if the Army were to offer a monthly wage of $\$ 2,000$ and a $\$ 501$ bonus for those who volunteered to deploy to the desert. Angie would gain $\$ 2,000$ $\$ 1,500=\$ 500$ if she were to reject the bonus and were stationed at Ft. Carson (the best possible outcome should she reject the bonus). But if she were to accept the bonus and be deployed to the desert with certainty, she would gain $\$ 2,000+$ $\$ 501-\$ 2,000=\$ 501$. As this exceeds $\$ 500$, Angie would accept the bonus and volunteer for the desert. Given Angie accepts the bonus and volunteers for the desert, Ben knows he will serve at Ft. Carson with certainty and is willing to reenlist at the current monthly base salary of $\$ 2,000$. Notice that with lower base salaries plus a bonus, the Army's payroll costs have declined relative to a single monthly wage sufficiently high to induce both Ben and Angie to reenlist ( $\$ 4,501$ vs. $\$ 5,000)$. Ben is equally well off, but Angie's surplus has declined under the bonus regime (\$501 vs. \$750). However, if the Army offered a bonus of \$750, the Army still has a reduced payroll relative to a single monthly salary ( $\$ 4,750$ vs. $\$ 5,000)$, Ben is equally well off, and Angie has the same surplus as she did under a monthly salary of $\$ 2,500 .^{7}$

\section{Game Theoretic Model and Notation}

Moving to the game theoretic analysis, assume a soldier of a given rank and job classification receives $\$ M$ in monetary compensation for his/her duties. ${ }^{8}$ If a soldier is assigned to an undesirable assignment, let there be some dollar amount that soldier would be willing to pay to trade for a desirable assignment. For simplicity, assume two possible values, $S_{1}$ and $S_{2}$, where $S_{1}<S_{2}$. In the language of economics, $S_{1}$ and $S_{2}$ represent the monetary disutility of serving in an undesirable assignment. Or, returning to the previous illustration, if Angie were assigned to the desert, she would be willing to pay $\$ 500$ to serve instead at Ft. Carson. Likewise, Ben would be willing to pay $\$ 1,000$ to be reassigned to Ft. Carson from the desert. Angie is a low-disutility soldier, while Ben is a highdisutility soldier. Any given soldier with probability $\alpha$ has disutility $S_{1}$, and with probability $(1-\alpha)$ has disutility $S_{2}$. For simplicity, assume all soldiers, regardless of whether they have low or high disutility, can earn a wage of $C$ in the civilian labor market if they choose to exit the Army.

The Army acts first in this game and must decide whether or not to offer a bonus, $B_{2}$, to soldiers who volunteer to serve at an undesirable location. Additionally, if the Army chooses to offer a bonus, they must also choose $\phi$, the probability of receiving a "bad" assignment if a soldier chooses to reenlist and decline the bonus. If the Army were omniscient, they would know both the disutility levels $S_{1}$ and $S_{2}$ and which soldiers were of what type. Given $S_{1}<S_{2}$, an omniscient Army would offer a bonus of $S_{1}$ to the low-disutility soldiers in return for them volunteering to serve in the undesirable location, as they are the least expensive personnel to induce to the undesirable location. However, the Army cannot observe a soldier's disutility $\left(S_{1}\right.$ or $\left.S_{2}\right)$ and, therefore, must either offer or not offer the bonus to all soldiers. 
Next, each soldier individually acts. If the Army decides to offer the bonus, soldiers have one of three choices: (1) reenlist and accept the bonus; (2) reenlist and decline the bonus; or (3) exit the Army. If they reenlist and accept the bonus, they serve at an undesirable location and receive a payoff, $M+B-S_{\text {i. }}$. If they reenlist and decline the bonus, then with probability $(1-\phi)$ they serve in a desirable location and receive a payoff, $M$, and with probability $\phi$ they serve in an undesirable location and receive a payoff, $M-S_{\mathrm{i}}$. If they decide to exit the Army, then they receive a payoff of $C$ from the civilian labor market.

If the Army decides not to offer a bonus, then personnel have to choose between reenlisting and exiting the Army. If they decide to reenlist, then with probability $(1-\delta)$ they serve in a desirable location and receive a payoff, $M$, and with probability $\delta$ they serve in an undesirable location and receive a payoff, $M-$ $S_{\mathrm{i}} .{ }^{9}$ Figure 1 depicts the TSRB game in extensive form with only soldiers' payoffs shown. ${ }^{10}$

In Figure 1, the first level of the tree represents nature's move in determining whether a soldier is high or low disutility for serving in an undesirable location. The second move is the Army's decision of whether or not to offer a bonus. The third move is the soldier's in determining whether or not to accept the bonus. If the bonus is not accepted, the soldier can further choose to exit the Army. Finally, if the soldier declines the bonus but chooses to remain in the Army or no bonus is offered, the Army has the choice of whether to send the soldier to a good assignment or a bad one.

The Army's goal is to maximize the number of soldiers who reenlist while inducing the targeted $^{11}$ number of soldiers to accept the bonus and serve at the undesirable location. For notational simplicity, assume the Army has one undesirable location. Let $v$ be the dollar value to the Army of having a soldier reenlist and $t(x)$ be the dollar cost to the Army of missing its targeted number of soldiers at the undesirable location by $x$ soldiers. Let $t$ be a nondecreasing function of $x$, and let $t(x)=0$ if $x \leq 0$. If $R$ represents the number of soldiers who reenlist when no bonus is offered and $K$ the number of soldiers required at the undesirable location, the Army's payoff function when no bonus is offered is equal to $v R-t(K-$ $\delta R)$. $R$ soldiers reenlist at a value to the Army of $v$ each. Recall $\delta$ is the probability a soldier serves in an undesirable location given no bonus is offered. $\delta R$ soldiers would be sent to the undesirable location. Given the required number of soldiers is $K, K-\delta R$ represents how many soldiers the Army falls short of the required amount. If a bonus is offered, the Army's payoff function is equal to $v\left(R_{b}+R_{n b}\right)-$ $t\left(K-R_{b}-\phi R_{n b}\right)$, where $R_{b}$ is the number of sol-

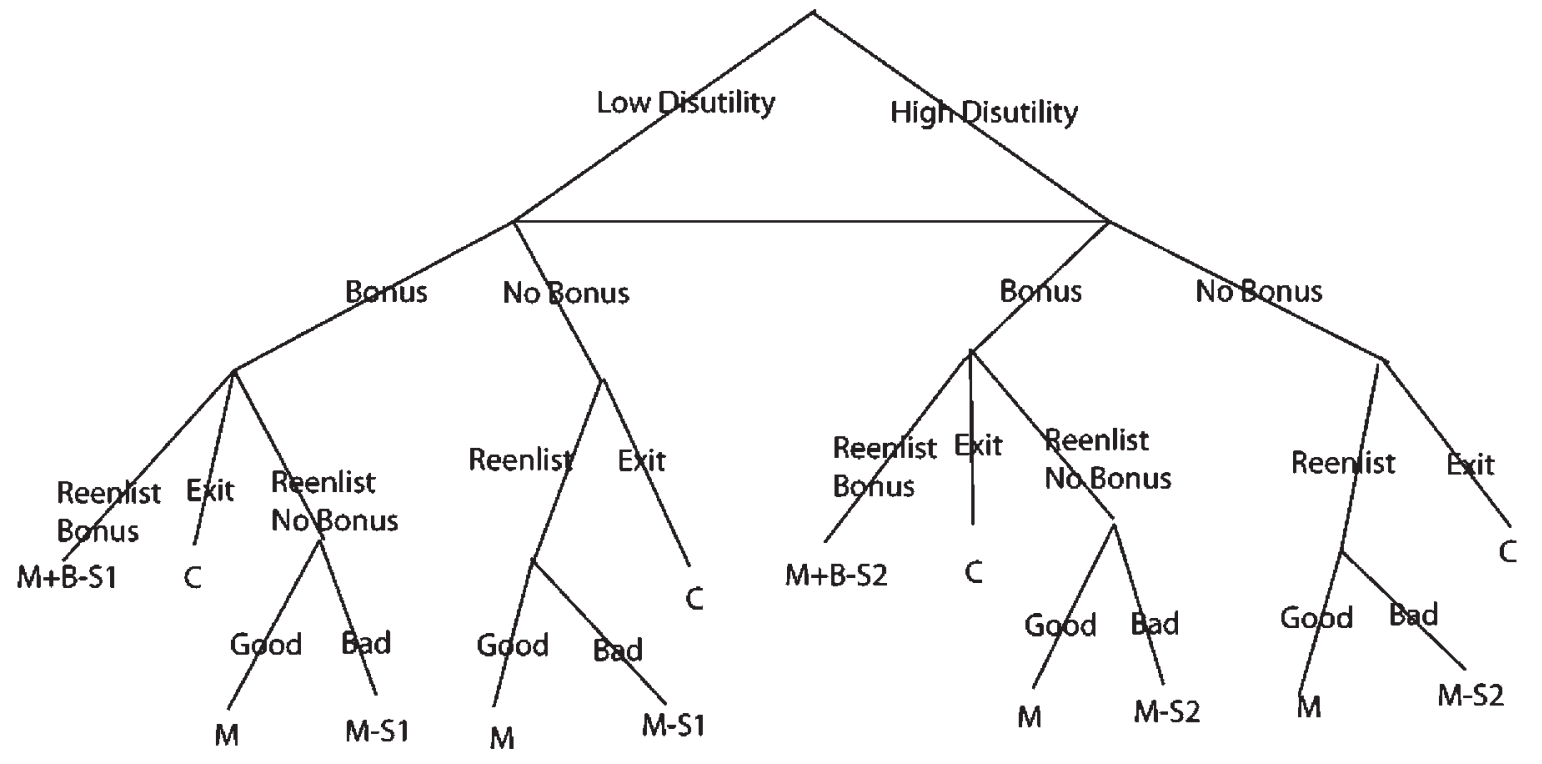

FIGURE 1. TSRB Game in Extensive Form 
diers who accept the bonus and reenlist and $R_{n b}$ the number of soldiers who decline the bonus and reenlist. Recall $B$ is the bonus amount offered and $\phi$ is the probability a soldier is involuntarily sent to the undesirable location given $\mathrm{s} /$ he declines the bonus. $B R_{b}$ is the dollar amount the Army spends on bonuses.

\section{PARAMETER ASSUMPTIONS}

To better conform model behavior to actual Army practices, we make the following parameter assumptions:

(1) $M-\delta S_{1}>C>M-\delta S_{2}$

(2) $\delta>0$

(3) $\delta \geqslant \phi$

In words, (1) assumes that before the Army decides whether or not to send a soldier to an undesirable location, the expected pay of a low-disutility soldier given they are sent with probability $\delta$ to an undesirable location exceeds what s/he could earn as a civilian, and that civilian pay exceeds the expected pay of a high-disutility soldier. Although this condition may at first seem arbitrary, a lowdisutility soldier could alternatively be thought of as one who enjoys the Army and prefers the Army to civilian life given the current risk of being sent to an undesirable location (Angie in the narrative). Likewise, a high-disutility soldier is one who would prefer to leave the Army for civilian life given the current risk of being sent to an undesirable location (Ben in the narrative). (2) implies that if the Army does not offer a bonus, some soldiers will be involuntarily sent to an undesirable location. (3) imposes the condition that the probability a soldier is involuntarily sent to the undesirable location is at least as large when there is no bonus offered as opposed to when there is a bonus offered. If this condition were not met, this would imply that the bonus is entirely ineffective and even counterproductive.

Assumption (1) ensures that when no bonus is offered, low-disutility soldiers will always reenlist, as their expected wage exceeds their next best opportunity as a civilian. Therefore, the branch of the game tree below Low Disutility, No Bonus in Figure 1 can now be simplified to reflect this. If low-disutility soldiers will never exit when no bonus is offered, they will never exit when a bonus is offered. By similar reasoning, high-disutility soldiers will always exit the Army when no bonus is offered. Therefore, the branch of the game tree below High Disutility, No Bonus can be simplified to Exit. When making his/her decision of whether to reenlist, the soldier has no knowledge of whether the Army will send him/her to the undesirable location or not. Therefore, from the view of the soldier, it is proper to further simplify the game tree in Figure 1 by omitting the fourth decision layer (good versus bad assignment) and replacing it with expected payoffs. Figure 2 incorporates all of these simplifying assumptions.

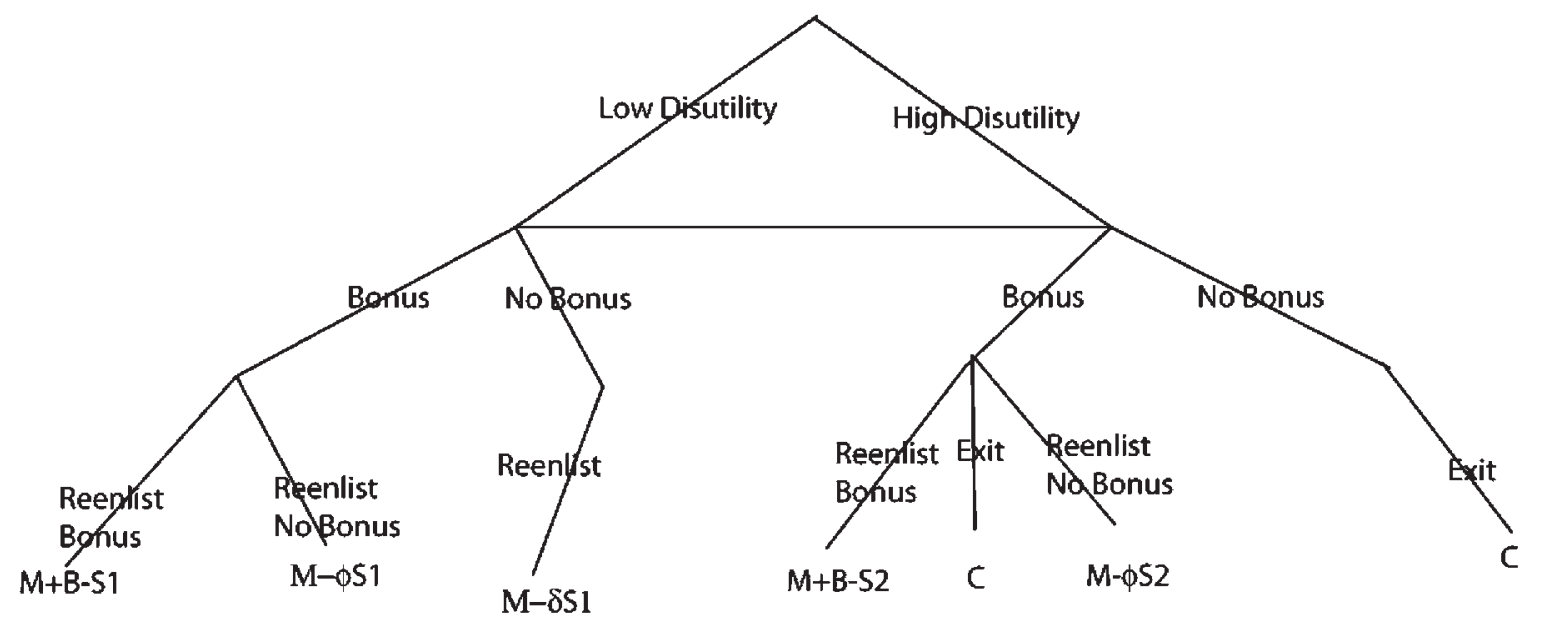

FIGURE 2. Extensive Form with Parameter Assumptions 


\section{EQUILIBRIUM CONDITIONS}

In its administration of the TSRB, the Army makes periodic changes in bonus amounts as needed. For instance, during the third quarter of 2002, the Army made 181 changes to the bonus multiples across occupations and locations. ${ }^{12}$ The Army makes discrete changes in increments of 0.5 to the bonus multiples that range from 0.5 to $3.0 .{ }^{13} \mathrm{Al}-$ though the Army offers six levels of bonuses $(0.5,1,1.5,2,2.5,3)$, for the sake of simplicity, consider three bonus ranges-zero, "small," and "large" —with precise mathematical definitions to be given below. Intuitively, consider a bonus to be "small" if some but not all eligible soldiers accept it and "large" if all eligible soldiers accept it. With the simplified game tree of Figure 2, now consider the Army's payoff for bonus amounts of zero, "small," and "large." Let $N$ be the number of soldiers in the Army eligible to reenlist.

\section{No Bonus Offered}

Examination of Figure 2 shows that under the assumptions made, low-disutility soldiers will always reenlist under all circumstances considered. High-disutility soldiers will exit the Army if no bonus is offered. Since $\alpha$ is the proportion of soldiers who are low-disutility, $\alpha N$ soldiers will reenlist. The Army's payoff is then

$$
\nu \alpha N-t(K-\alpha n)
$$

where $K-\alpha N$ represents the shortfall of soldiers at the undesirable location.

\section{All Accept Bonus}

For low-disutility soldiers to accept the bonus, a soldier's payoff for taking the bonus and being assigned to the undesirable location with certainty must exceed the payoff of reenlisting, declining the bonus, and being assigned to the undesirable location with probability $\phi$. Let this bonus amount be designated $B_{1}$. Mathematically, this condition is $M+B_{1}-S_{1}>M-\phi S_{1}$, or consolidating like terms and rearranging, $B_{1}>(1-\phi) S_{1}$. Likewise, for high-disutility soldiers to accept the bonus, their payoff for accepting the bonus and being assigned to the undesirable location must both exceed the payoff from exiting the Army and exceed the payoff of reenlisting, declining the bonus, and being assigned to the undesirable location with probability $\phi$. Mathematically, the latter condition can be expressed as $M+B_{1}-S_{2}>M$ - $\phi S_{2}$, or consolidating like terms and rearranging, $B_{1}>(1-\phi) S_{2}$. Since $S_{2}>S_{1}$, this condition implies a larger bonus than the previous one. To ensure high-disutility soldiers don't exit the Army, $M+B_{1}-S_{2}>C$ or $B_{1}>C$ $-M+S_{2}$. With $B_{1}$ fulfilling these conditions, all $N$ eligible soldiers reenlist. The Army meets its targeted number of soldiers in the undesirable location but must pay bonuses to all. Its payoff is

$$
v N-B_{1} N
$$

In its administration

of the TSRB, the

Army makes

periodic changes in

\section{Some Accept Bonus}

Above, we established that lowdisutility soldiers will accept a bonus if $B>(1-\phi) S_{1}$ and highdisutility soldiers will accept a bonus if $B>(1-\phi) S_{2}$. Consider a bonus amount $B_{2}$, such that $(1-\phi) S_{1}<B_{2}<$ $(1-\phi) S_{2}$. Low-disutility soldiers would accept $B_{2}$ and agree to be sent to the undesirable location, while high-disutility soldiers would not accept the bonus and $\phi$ percent would be sent to the undesirable location. If $\phi$ is set so that the army meets its targeted number of soldiers in the undesirable location, the sum of all low-disutility soldiers and the proportion of high-disutility soldiers sent to the undesirable location would equal the target. Mathematically, $\alpha N+\phi(1-\alpha) N$ $=K$. Rearranging to solve for $\phi$,

$$
\phi=\frac{K-\alpha N}{(1-\alpha) N}
$$

The numerator, $K-\alpha N$, represents the number of high-disutility soldiers needed in the undesirable location. The denominator, $(1-\alpha) N$, is the total number of highdisutility soldiers. $\phi$ is, therefore, the propor- 
tion of high-disutility soldiers who serve in the undesirable location.

If the payoff to high-disutility soldiers of reenlisting but declining the bonus exceeded the payoff from exiting the Army, $M-\phi S_{1}>C$, high-disutility soldiers would reenlist and decline the bonus, and $\phi$ percent will be assigned to the undesirable location. Rearranging the previous inequality, $M-C>\phi S_{2}(M-C)$ is the pay premium a high-disutility soldier who declines the bonus receives over the wage s/he could earn as a civilian. $\phi S_{2}$ is the disutility of serving in an undesirable location weighted by the probability of serving there, or the expected disutility of serving in an undesirable location. To repeat, this condition must be met for high-disutility soldiers who decline the bonus to reenlist. Assuming this condition is met, the Army's payoff is

$$
v N-B_{2} \alpha N
$$

Table II shows the Army's payoff for the three bonus amounts discussed above, arranged in ascending bonus amounts.

Given $B_{2}<B_{1}$ and $\alpha<1$, the Army's payoff from offering the smaller bonus, $B_{2}$, exceeds the payoff of the larger bonus, $B_{1}$. Thus, the Army will never choose to offer a bonus so large that all soldiers accept, and the large bonus can be removed from consideration. Subtracting the Army's payoff when no bonus is offered from the payoff when $B_{2}$ is offered, the difference is $v(1-\alpha) N$ $+t(1 \mathrm{~K}-\alpha N)-\alpha N B_{2}$. In words, it is the value to the Army of high-disutility soldiers reenlisting plus the cost to the Army of being undermanned due to high-disutility soldiers exiting the Army, less the cost of bonuses required to induce low-disutility soldiers to accept assignments in the undesirable loca- tion. Given severe enough manning shortages, the magnitude of the first two terms likely would exceed that of the third, making this term positive and implying that the Army would receive a larger payoff from offering the bonus $B_{2}$ than not offering a bonus.

Therefore, the sequential equilibrium for the Army's Targeted Selective Reenlistment Bonus Program is for the Army to offer a bonus in the range $(1-\phi) S_{1}<B<(1-\phi) S_{2}$. Low-disutility soldiers will accept the bonus and be assigned to the undesirable location, while high-disutility soldiers will reenlist and decline the bonus, and $\phi$ percent will be assigned to the undesirable location. Compared to not offering a bonus, the resulting equilibrium increases the number of soldiers who reenlist, while minimizing the bonus amount paid by the Army. Additionally, a greater number of soldiers serve in the undesirable location.

\section{HUMAN RESOURCE MANAGEMENT IMPLICATIONS}

Economists talk of policy changes being a Pareto improvement if at least one party to a transaction is made better off without making any other party worse off. Offering increased pay through bonuses quite obviously makes soldiers better off. Our narrative and game theoretic model has demonstrated that the Army, too, can gain from the TSRB program, a point much less obvious. We mention above that the Army frequently changes the dollar amount of the bonus offered under the TSRB. As past program data are reviewed and changes contemplated for bonus amounts, our model implies the fol-

\section{T A B L E I I Army Payoff for Ascending Bonus Amounts}

\section{Bonus Amount}

0

$B_{2}$

$B_{1}$

\section{Army Payoff}

$v \alpha N-t(K-\alpha N)$

$v N-B_{2} \alpha N$

$v N-B_{1} N$ 
lowing human resource management advice to the Army:

- A bonus that is universally accepted is too large and needs to be reduced. A universally accepted bonus is tantamount to an increase in basic pay and does not help the Army distinguish low-disutility soldiers from high-disutility soldiers.

- Soldiers who decline the bonus must perceive that their probability of being sent to an undesirable location has been reduced by the TSRB. Our analysis shows that a bonus not universally accepted will be accepted by low-disutility soldiers only (Angie in the narrative). Their behavior has not been changed by the bonus, as they would have chosen to remain in the Army regardless of whether a bonus was offered or not. By accepting the bonus, low-disutility soldiers have agreed with perfect certainty to be sent to an undesirable location. Having declined the bonus, high-disutility soldiers (Ben in the narrative) will abandon plans to exit the Army and reenlist only if their probability of being sent to an undesirable location is reduced sufficiently.

- Basic Army pay must exceed the alternative civilian wage by at least enough to compensate for the expected risk/cost of being sent to an undesirable location. Otherwise, highdisutility soldiers will leave the Army and the bonus will not affect retention rates.

Although our study is centered on the Army's Targeted Selective Reenlistment Bonus program, we believe our study has relevance and application beyond the military to other organizations operating in a variety of geographic locations with rules-based compensation. The U.S. Postal System and Federal Civil Service are examples. Other possible applications might be large, hierarchical firms, such as IBM, that send certain classes of employees to remote or high-risk locations, or a large oil production company with offshore and onshore drilling, or an evening janitorial company operating in high-crime and low-crime localities. Fully flexible wages, in theory, should obviate local labor short- ages. But certain types of organizations may still choose rules-based wages for the benefits noted in the literature review. Location-specific bonuses are an effective way of introducing geographic variation into wages while maintaining a rules-based wage structure.

\section{CONCLUSION}

Our analysis of the Army's TSRB program as a sequential game shows that the program increases the number of soldiers who reenlist and the number of soldiers who serve in undesirable locations. This equilibrium results in soldiers with the lowest opportunity cost for serving in undesirable locations accepting the bonus and serving in these locations. Additionally, those soldiers with high opportunity costs for serving in undesirable locations are induced to reenlist because their probability of serving in undesirable locations is minimized.

In addition to increasing the overall reenlistment rate, the TSRB program reduces the opportunity costs for soldiers serving in undesirable locations. Reducing the opportunity costs at each location will likely lead to increases in the long-term reenlistment rate, better morale, and decreased moving expenses for the Army.

However, a possible concern

Our analysis of the

Army's TSRB

program as a

sequential game

shows that the

program increases

the number of

soldiers who reenlist

and the number of

soldiers who serve

in undesirable

locations. with the TSRB program is the large number of changes in the bonus offerings from quarter to quarter. The concern arises from the potential adverse affects associated with the uncertainty of future bonuses and risk-averse personnel (Asch \& Hosek, 1999).

Despite this concern, the Army's geographically targeted program appears to have a clear advantage over purely occupational reenlistment bonus programs. Occupational bonus programs only vary reenlistment bonuses at the national level, and therefore provide no incentive for personnel to volunteer to serve in an undesirable location. Although occupa- 
tional bonus programs increase the overall reenlistment rate, they are analogous to the case considered above in which a bonus is offered and all accept. This approach does not solve the geographic sorting problem for personnel with heterogeneous preferences. On the other hand, the Army's targeted program provides a partial ${ }^{14}$ mechanism to sort personnel. That is, those soldiers who choose to accept a TSRB are those who have the lowest opportunity cost for serving at that location among those who reenlist.

SCOTT E. CARRELL is a visiting assistant professor of economics and the director of the Policy Research Shop at the Nelson A. Rockefeller Center at Dartmouth College. He received his PhD in economics from the University of Florida in 2003. Before coming to Dartmouth, he taught at the U.S. Air Force Academy for two years and served as the Senior Economist for Public Finance and Labor on the staff of the President's Council of Economic Advisers during the summer of 2004. He also served as an active-duty officer in the U.S. Air Force for over ten years. He specializes in the fields of education policy, social interactions, and empirical labor.

JAMES E. WEST is an associate professor of economics at the U.S. Air Force Academy, where he has been a member of the faculty since 1997. He received his PhD in economics from the University of Michigan in 1994, specializing in public finance and econometrics. His research interests are in the fields of public policy, social interactions, and applied econometrics.

\section{NOTES}

1. BAS varies slightly across enlisted and officer ranks, but not within enlisted ranks.

2. A Permanent Change of Station is when a sailor/soldier/airman is assigned to a new duty location or military base on a permanent basis. It is, in essence, a job-related move.

3. Navy detailers have the option of selecting other than the low-cost sailor with a documented rationale. See Hogan and Mackin (2003) for more details.

4. Figures from Department of the Army, FY03 Budget Estimates, submitted to Congress, February 2002.

5. This assumes personnel have already reenlisted or have sufficient time remaining on their current enlistment.

6. For more regarding the efficiencies of a voluntary system of assignments, reference Carrell (2006).

7. Under the bonus scenario, Angie receives a surplus of $\$ 750$ with certainty, while with a monthly salary of $\$ 2,500$ and random assignments, she receives a $\$ 1,000$ surplus with probability 0.5 and $\$ 500$ with probability 0.5 . If Angie is riskaverse, she will prefer $\$ 750$ with certainty to $\$ 750$ in expectation.

8. See Appendix A for a complete list of notations and definitions.

9. The model assumes the probability $\delta$ is exogenously determined and known to all players. Additionally, $\delta$ is assumed to be the government's "optimized value" when no bonus is offered.

10. The Army's payoffs are not shown in extensive form because the Army's payoff is a function of how soldiers of both types act, and therefore is indeterminate at an individual node.

11. We assume that the Army would like to induce only the required number of personnel to serve at undesirable locations.

12. The 181 changes do not include the number of changes made within each rank or term of reenlistment. Additionally, the number of bonus changes is a consistent trend over time with 189 changes made from April to June 2002. Data obtained from MILPER MESSAGES 02-225 and 02-174. 
13. The amount of the bonus is computed by multiplying the bonus multiple by the soldier's monthly base pay by the number of years of the reenlistment.

14. The TSRB program is only a partial sorting mechanism, because no sorting occurs among those personnel who are not eligible for reenlistment and are due for a permanent change of station.

\section{REFERENCES}

Asch, B. J., \& Hosek, J. R. (1999). Military compensation:Trends and policy options. Santa Monica, CA: Rand, National Defense Research Institute.

Asch, B. J., \& Warner, J. T. (2001). A theory of compensation and personnel policy in hierarchical organizations with application to the United States Military. Journal of Labor Economics, 19, 523-562.

Baker, G., Gibbs, M., \& Holmstrom, B. (1994) The internal economics of the firm: Evidence from personnel data. Quarterly Journal of Economics, 109, 881-919.

Barber, A. E. (1998). Recruiting employees. Thousand Oaks, CA: Sage.

Blomquist, G. C., Berger, M. C., \& Hoehn, J. P. (1988). New estimates of quality of life in urban areas. American Economic Review, 78, 89-107.

Brown, C. (1985). Military enlistments: What can we learn from geographic variation? American Economic Review, 75, 228-234.

Carrell, S. E. (2006). The national internal labor market encounters the local labor market: Effects on employee retention. Labour Economics, forthcoming.

Carrell, S. E., \& West, J. E. (2005). The optimal compensating wage for military personnel. Journal of Policy Analysis and Management, 24, 803-822.

Daula, T., \& Moffitt, R. (1995). Estimating dynamic models of quit behavior: The case of military reenlistment. Journal of Labor Economics, 13, 499-523.

Delery, J., Gupta, N., Shaw, J. L., Jenkins, G. D., \& Ganster, D. (2000). Unionization, compensation, and voice effects on quits and retention. Industrial Relations, 39, 625-646.

Doeringer, P. B., \& Piore, M. J. (1971). Internal labor markets and manpower analysis. Lexington, MA: Heath.

Fullerton, R. L. (2003). An empirical assessment of US
Air Force pilot attrition. Defence and Peace Economics, 14, 343-355.

Gibbs, M., \& Hendricks, W. (2004). Do formal salary systems really matter? Industrial and Labor Relations Review, 58, 71-92.

Graves, P. E., Arthur, M. M., \& Sexton, R. L. (1999). Amenities and the labor earnings function. Journal of Labor Research, 20, 367-376.

Guthrie, J. P. (2000). Alternative pay practices and employee turnover: An organizational economics perspective. Group \& Organization Management, 25, 419-439.

Haurin, D. R. (1980). The regional distribution of population, migration, and climate. Quarterly Journal of Economics, 95, 293-308.

Herzberg, J., Mausner, B., Peterson, R. O., \& Capwell, D. F. (1957). Job attitudes: Review of research and opinion. Pittsburgh: Psychological Service of Pittsburgh.

Hogan, P. F., \& Mackin, P. C. (2003). Voluntary assignments and economic efficiency, Presented at the Western Economic Association International Meetings, Denver, CO.

Hom, P., \& Griffeth, R. W. (1995). Employee turnover. Cincinnati, $\mathrm{OH}$ : South-Western.

Hosek, J. R., \& Peterson, C. E. (1985). Reenlistment bonuses and retention behavior. Santa Monica, CA: Rand, National Defense Research Institute.

Jaffe, G. (2003, August 11). Navy turns into auctioneer, lets sailors bid for job posts. Wall Street Journal, p. B1.

Jurgensen, C. E. (1978). Job preferences (what makes a job good or bad?). Journal of Applied Psychology, 63, 267-276.

Lawler, E. E., III. (1971). Pay and organizational effectiveness: A psychological view. New York: McGraw Hill.

MCPON Minute. (2004, May 16). Challenging Assignments-AIP Week of 16 May 2004, United States Navy, http://www.chinfo.navy.mil/navpalib/ mcpon/minutes/2004/chaass04.txt

Milgrom, P. (1988). Employment contracts, influence activities, and efficient organization design. Journal of Political Economy, 96, 703-736.

Milgrom, P., \& Roberts, J. (1988). An economic approach to influence activities in organizations. American Journal of Sociology, 94, S154-S179.

Prendergast, C. (1993). A theory of 'yes men.' American Economic Review, 83, 757-770. 
Prendergast, C., \& Topel, R. (1996). Favoritism in organizations. Journal of Political Economy, 104, 958-978.

Rosen, S. (1979). Wage-based indexes of urban quality of life. In P. Mieszkowski \& M. Straszheim (Eds.), Current issues in urban economics (pp. 74-104). Baltimore, MD: Johns Hopkins University Press.

Rynes, S. L., Schwab, D. P., \& Heneman, H. G. (1983). The role of pay and market pay variability in job application decisions. Organizational Behavior and Human Performance, 31, 353-364.

Rynes, S. L., Gerhart, B., \& Minette, K. A. (2004). The importance of pay in employee motivation: Discrepancies between what people say and what they do. Human Resource Management, 43, 381-394.
Saving, T. R., Stone, B. M., Looper, L. T., \& Taylor, J. N. (1985). Air Force enlisted personnel: An empirical examination of Air Force enlisted personnel. Air Force Human Resources Laboratory, Air Force Systems Command, U.S. Department of the Air Force.

Schwab, D. P. (1982). Recruiting and organizational participation. In K. M. Rowland \& G. R. Ferris (Eds.), Personnel management (pp. 103-128). Boston: Allyn and Bacon.

Towers Perrin. (2003). Working today: Understanding what drives employee engagement. The 2003 Towers Perrin Report.

Warner, J. T., \& Goldberg, M. S. (1984). The influence of nonpecuniary factors on labor supply: The case of Navy enlisted personnel. Review of Economics and Statistics, 66, 26-35.

\section{A P P E N D I X A Notation and Definitions}

$\alpha \quad$ Probability a given soldier has disutility level $\mathrm{S}_{1}$

$\delta \quad$ Probability a soldier receives an undesirable assignment, given no bonus offered

$\phi \quad$ Probability a soldier who declines a bonus is given an undesirable assignment

$B \quad$ Bonus amount Army offers soldier who reenlists

$C \quad$ Civilian wage available upon exit from the Army

$K \quad$ Number of soldiers required at a given undesirable location

$M \quad$ Monetary compensation a soldier receives

$N \quad$ Number of soldiers in the Army eligible to reenlist

$R \quad$ Number of soldiers who reenlist when no bonus is offered

$R_{b} \quad$ Number of soldiers who accept the bonus and reenlist

$R_{n b} \quad$ Number of soldiers who decline the bonus and reenlist

$S_{l} \quad$ Payment a low-disutility soldier would make to receive a desirable assignment

$S_{2} \quad$ Payment a high-disutility soldier would make to receive a desirable assignment

$t(x)$ Dollar cost to the Army of missing its targeted number of soldiers at a given undesirable

location by $x$ soldiers. $t$ is a nondecreasing function of $x . t(x)=0$ if $x \leq 0$

$v \quad$ Dollar value to the Army of having a soldier reenlist 